Asian-Australasian Journal of

Food Safety and Security

ISSN 2523-1073 (Print) 2523-2983(Online)

www.ebupress.com/journal/aajfss

\title{
Article \\ Isolation, identification and antibiogram profile of Aeromonas hydrophila from broiler chickens in Mymensingh Sadar, Bangladesh
}

\author{
Basana Sarker ${ }^{1 \mathrm{a}}$, Mohammad Arif ${ }^{2 \mathrm{a}}$, Nilofa Eashmen ${ }^{1}$, Mir Rowshan Akter ${ }^{1}$ and S. M. Lutful Kabir ${ }^{2 *}$ \\ ${ }^{1}$ Department of Microbiology, Hajee Mohammad Danesh Science and Technology University, Dinajpur-5200, \\ Bangladesh \\ ${ }^{2}$ Department of Microbiology and Hygiene, Bangladesh Agricultural University, Mymensingh-2202, \\ Bangladesh
}

${ }^{a}$ Basana Sarker and Mohammad Arif contributed equally to this work

*Corresponding author: Professor Dr. S. M. Lutful Kabir, Department of Microbiology and Hygiene, Bangladesh Agricultural University, Mymensingh-2202, Bangladesh. Phone: +8801754987218; E-mail: lkabir79@bau.edu.bd

Received: 20 April 2020/Accepted: 27 May 2020/ Published: 30 May 2020

\begin{abstract}
Investigation of Aeromonas hydrophila was conducted to assess the microbial quality of broiler chickens from July to November 2019. A total of 60 samples from 20 broiler chickens were collected from two different locations of Mymensingh Sadar: KR market, Bangladesh Agricultural University (BAU) and Shesh mor bazar (10 birds from each location). Samples included 20 skins, 20 legs and 20 breast samples from 20 broiler chickens. PCR was done for the specific detection of each isolate and finally antimicrobial susceptibility testing was performed to check sensitivity pattern of each isolate. Alkaline peptone water was used for processing and enrichment of the samples followed by inoculation onto Aeromonas selective agar supplemented with ampicillin for the isolation and identification of $A$. hydrophila. Out of these 60 samples, 27 isolates were confirmed as A. hydrophila through biochemical tests and PCR where 55.56\% isolates were recovered from Shesh mor market and other $44.4 \%$ isolates from KR market, BAU. Source-wise analysis revealed that maximum isolates of $A$. hydrophila were recovered from skin (59.26 \%) followed by leg (22.22 \%) and breast samples (18.52\%). PCR test revealed that all 27 isolates were found carrying lip gene which is specific for $A$. hydrophila. Isolates of $A$. hydrophila were found sensitive to ciprofloxacin (92\%), gentamycin (66\%) and chloramphenicol (50\%); intermediate against erythromycin (50\%), tetracycline (50\%) and imipenem (50\%); resistant against co-trimoxazole (84\%) and ampicillin (100\%). From the present study, it was found that samples were considerably contaminated with Aeromonas hydrophila causing risks for public health. Necessary control actions should be taken in every steps of production, processing and marketing for mitigation of this contamination.
\end{abstract}

Keywords: broiler chickens; Aeromonas hydrophila; molecular identification; antibiogram profile

\section{Introduction}

Bangladesh is an agro based country. As such poultry rearing is considered superior to the others in the agricultural sector because of a relatively short period of time to harvest. Besides, among the animal protein sources commercial poultry production ranks highest (Iyayi et al., 2008). As a result rapid growth of poultry industry has been occurring around the world than other food-producing animal industries. The trade volume of poultry products has also increased parallel to the rapid growth of global poultry industry (Windhorst et al., 2006). In Bangladesh, broiler meat is an important and low-cost source of animal protein that encourages the consumption of broiler meat by a large amount of consumers. The modern poultry industry can produce market 
ready broiler chickens in $<3$ weeks through genetic selection, improved feeding and keen health management practices including usage of antibiotics as growth promoter, preventive and therapeutic agents in intensive farming systems. This irrational use of antibiotics in poultry is one of the important issues for the development of microbial resistance to antibiotics. The rise in antibiotic resistance has been reported in the past two decades in many countries including Bangladesh (Akond et al., 2009). Foodborne diseases and poisoning are the widespread and great public health concerns of the modern world in both developed and developing countries. Food contaminated with pathogenic microorganisms are considered as a threat for public health which may lead to serious food poisoning outbreaks (Bagde and Tumane, 2011). Among these microorganisms Aeromonas spp. are also considered as a major cause of food-borne human disease in most parts of the world at present (Soultose et al., 2003).

The genus Aeromonas consists of two different groups of bacteria. One is non-motile psychrophilic Aeromonas salmonicida and the other group includes three mesophilic motile spp. A. hydrophila, A. caviae, and A. sobria (Praveen et al., 2014). Aeromonas is an environmental microorganism that inhabits a wide range of ecosystems including aquatic environment (Wei et al., 2015; Garibay et al., 2006). Besides these aeromonads occur as the normal microbial flora of many aquatic and terrestrial animals including fishes, amphibians, reptiles, birds and other domestic animals (Gowda et al., 2015). Along with aquatic environment, different foods, especially, fishes and other seafood, raw and cooked meat, chicken, vegetables, milk and milk products play an important role in the dissemination of aeromonads (Khajanchi et al., 2010; Ghenghesh et al., 2008; Fricker and Tompsett, 1989). The risk of foodborne Aeromonas infections has been increasing as Aeromonas spp. are frequently isolated from food due to their psycrotrophy and the existence of the pathogens in water and fecal materials of humans and animals (Albert et al., 2000). Poultry and poultry products are frequently contaminated with Aeromonas spp. that can be transmitted to humans through the handling of raw poultry carcasses and products, or through consumption of undercooked poultry meat (Bailey and Cosby, 2003). Contamination of poultry meat during processing, handling, marketing, and storage prior to cooking, can lead to food poisoning illness in humans (Rajakumar et al., 2012; Nagar et al., 2011; Ghenghesh et al., 2008).

In the last few decades Aeromonas spp. have emerged as an important human pathogen (Praveen et al., 2014). The pathogenesis of Aeromonas infections is multifactorial and poorly understood (Janda and Abbott, 2010). There are several evidences of their involvement in gastrointestinal and extraintestinal infection in human (Gowda et al., 2015) due to the production of many putative virulence factors (Yucel and Erdogan, 2010). Aeromonas is considered as opportunistic pathogens in both immunocompetent and immunocompromised humans (Janda and Abbott, 2010). Besides foodborne gastroenteritis in human, some extraintestinal symptoms such as; septicemia, wound infections, meningitis, endocarditis and osteomyelitis (Stelma, 1988) with a high mortality rate in immunocompromised person have been documented. Principal virulence factors that have an effect on pathogenicity are; extracellular toxins (enterotoxin, hemolysin and protease), structural features (Pilli, S- layer, lipopolysaccharide), adhesion and invasion. Aeromonas spp. can grow and produce toxins in refrigerated conditions indicating that refrigeration sometimes seems to be ineffective to control the pathogens (Koca and Sarimehmetoglu, 2009). It is certain that Aeromonas strains may produce many different putative virulence factors such as enterotoxins, hemolysins or cytotoxins, and antibiotic resistance against different antibiotics. The ability of these bacteria to grow competitively at $5^{\circ} \mathrm{C}$ may be indicative of their potential as a public health hazard. Therefore, the present work is designed for isolation, identification and antibiogram profile of Aeromonas hydrophila from broiler chickens.

\section{Materials and Methods}

\subsection{Sample collection and processing}

This study was conducted during the period from July to November, 2019 to isolate Aeromonas hydrophila from different broiler samples in the laboratory of the Department of Microbiology and Hygiene, Bangladesh Agricultural University, Mymensingh. A total of 60 samples from 20 broiler chickens were collected from two different locations of Mymensingh Sadar: KR market, BAU and Shesh mor bazar (10 birds from each location). The samples included 20 skins, 20 legs and 20 breast samples from 20 broiler chickens (Table 2). Collected samples were immediately brought to the laboratory maintaining proper cool chain and processed as early as possible with $1 \%$ alkaline peptone water (HiMedia).

\subsection{Cultural and biochemical characterization}

Isolation of Aeromonas hydrophila from boiler samples was performed following the procedures described by Koca and Sarimehmetoglu (2009) with some modifications. $25 \mathrm{~g}$ of each samples were taken, placed in sterile zipper bags and homogenized with $225 \mathrm{ml}$ of $1 \%$ alkaline peptone water (HiMedia) and incubated at $30^{\circ} \mathrm{C}$ for 
24 hours. After incubation, enrichment fluid was streaked on Aeromonas selective agar (HiMedia) with ampicillin supplement and incubated at $30^{\circ} \mathrm{C}$ for 24 hours. Following the incubation, dark green centered green translucent colonies were further sub-cultured until pure culture of bacteria was obtained. Presumptive Aeromonas hydrophila isolates were stored in $20 \%$ glycerol at $-80^{\circ} \mathrm{C}$ until further use. The isolated bacteria were identified according to their biochemical characteristics (Ahammed et al., 2016; Samal et al., 2014).

Identification of the isolated Aeromonas hydrophila was done based on detailed morphological, physiological and biochemical characterization. The isolated bacteria were sub-cultured onto TSA plates to obtain fresh 24 hours culture. Colonies grown on the TSA plates were subjected to biochemical tests. Characters such as motility, size and shape of the bacterium were recorded under morphological studies. Physiological characters included growth of each isolate at different temperature of $4^{\circ} \mathrm{C}, 5^{\circ} \mathrm{C}, 37^{\circ} \mathrm{C}$ and $40^{\circ} \mathrm{C}$ as well as growth of each isolate in nutrient broth containing different concentrations of $\mathrm{NaCl}$ as $0 \%, 1 \%, 2 \%, 3 \%, 3.5 \%$ and $4 \%$. Different biochemical tests were conducted to evaluate the biochemical characteristic of the isolated bacteria such as oxidase, catalase, oxidative-fermentative test, esculin hydrolysis test, acid and gas production from sugars: glucose, lactose, sucrose, mannitol; methyl-red (MR) test, voges-Proskauer (VP) test, indole and $\mathrm{H}_{2} \mathrm{~S}$ production, decarboxylase test and citrate utilization test.

\subsection{Molecular identificaion of Aeromonas hydrophila by PCR}

Template DNA preparation was carried out by boiling method. Cultures were grown in nutrient broth at $37^{\circ} \mathrm{C}$ for $24 \mathrm{hrs}$ and $1 \mathrm{ml}$ of the overnight culture was centrifuged at 5,000 rpm for 3 minutes using eppendorf tubes. Supernatant was carefully removed and the pellet was resuspended with $200 \mu \mathrm{l}$ of sterile TE buffer, boiled at $100^{\circ} \mathrm{C}$ for 15 minutes and immediately incubated on ice for 10 minutes. The mixture was then centrifuged at $12,000 \mathrm{rpm}$ for 10 minutes and the supernatant with template DNA were then transferred into sterile tubes and stored at $-80^{\circ} \mathrm{C}$ for PCR amplification.

PCR was performed as per the method described previously by Swaminathan et al. (2004) with some modifications. Amplification of lip gene was performed to identify Aeromonas hydrophila with a DNA thermal cycler (Thermo cycler, ASTEC, Japan) using previously published primers. The list of primers is shown in Table 1. PCR reactions were carried out with $20 \mu \mathrm{l}$ volume that includes $6 \mu \mathrm{l}$ deionized water, $1 \mu \mathrm{l}$ forward primer (Macrogen Inc., Korea), $1 \mu \mathrm{l}$ reverse primer (Macrogen Inc., Korea), $2 \mu$ l DNA template and $10 \mu 1$ master-mix (Promega, USA). PCR reactions were done by following conditions: initial denaturation with 1 cycle of $4 \mathrm{~min}$ at $94^{\circ} \mathrm{C}$, followed by 40 cycles, each consisting of denaturation at $94^{\circ} \mathrm{C}$ for $1 \mathrm{~min}$, annealing at $69^{\circ} \mathrm{C}$ for $1 \mathrm{~min}$, extension at $72^{\circ} \mathrm{C}$ for $1 \mathrm{~min}$ and a final extension step of $5 \mathrm{~min}$ at $72^{\circ} \mathrm{C}$. After PCR reaction, PCR products were subjected to gel electrophoresis with $1.5 \%$ agarose gel at 100 volts for 45 minutes. Then the gel was submerged in ethidium bromide at a final concentration of $4 \mathrm{mg} / \mathrm{ml}$ for 15 minutes in a dark place followed by washing with distilled water for 5 minutes. Afterwards, the DNA was visualized under UV transilluminator (Biometry, Germany).

Table 1. Primers used for the molecular identification of Aeromonas hydrophila.

\begin{tabular}{llll}
\hline Primers & Sequence $\left(\mathbf{5}^{\prime}-\mathbf{3}^{\prime}\right.$ ) & Amplicon size (bp) & Reference \\
\hline lip-F & AACCTGGTTCCGCAAGCCG & \multirow{2}{*}{760} & Swaminathan et al. (2004) \\
lip-R & TTGCCTCGCCTCGGCCCAGCAGCT & & \\
\hline
\end{tabular}

\subsection{Antimicrobial susceptibility testing}

Eight different antimicrobial discs: ampicillin $(10 \mu \mathrm{g})$, chloramphenicol $(30 \mu \mathrm{g})$, co-trimoxazole $(25 \mu \mathrm{g})$, ciprofloxacin $(5 \mu \mathrm{g})$, erythromycin $(15 \mu \mathrm{g})$, gentamycin $(10 \mu \mathrm{g})$, imipenem $(10 \mu \mathrm{g})$ and tetracycline $(30 \mu \mathrm{g})$ were selected for the antimicrobial susceptibility test against 12 isolated Aeromonas hydrophila. All the antimicrobial discs were purchased from HiMedia, India.

Antibiotic susceptibility of the isolates was determined using the disc diffusion or Kirby-Bauer method (Bauer et al., 1966). Stock cultures of the bacterial strains were grown on TSA for $24 \mathrm{~h}$ at $37^{\circ} \mathrm{C}$. Then colonies of each of the isolate were adjusted to $0.5 \mathrm{McFarland}$ 's turbidity standard (equivalent to $1 \times 10^{8}$ colony forming unit $/ \mathrm{ml}$ ) in sterile phosphate buffered saline (PBS) and the bacterial suspension was spread onto Mueller-Hinton agar (Oxoid). Antibiotic-impregnated discs were kept on the solid medium and the plates were incubated at $37^{\circ} \mathrm{C}$ for $24 \mathrm{~h}$. Zone of inhibition formed around the discs was measured and antibiotic sensitivity was assayed from the length of the diameter of the zones (in $\mathrm{mm}$ ). The zone radius was actually scaled from the centre of the antibiotic disc to the end of the clear zone where bacteria could be seen growing. Tested bacterial strains were 
classified into three categories: sensitive, intermediate, and resistant depending on the diameters of inhibition zones and standards supplied by HiMedia Laboratories and comparing with other related references (Table 4).

\section{Results and Discussion}

\subsection{Occurrence of Aeromonas hydrophila}

In this study, a total of 60 samples were assessed for isolation and identification of Aeromonas hydrophila from poulty sources. From these 60 samples, 30 samples (10 skin, 10 leg and 10 breast samples) were collected from KR market, Mymensingh Sadar and another 30 samples (10 skin, 10 leg and 10 breast samples) were collected from Shesh mor bazar, Mymensingh Sadar. Out of 60 samples, a total of 37 isolates showed positive growth on Aeromonas Selective Agar plates (HiMedia, India) and produced greenish with dark green centre, round, small to medium, convex and translucent colonies. In this study, out of 60 different poultry samples, 27 (45\%) samples were positive for Aeromonas hydrophila based on biochemical and molecular test (Table 2). The above result is quite similar with the results reported by Dallal et al. (2012), Koca and Sarimehmetoglu (2009) and Ternstrom and Molin (1987) who had found 41\%, 53.75\% and 53.3\% positive Aeromonas hydrophila respectively from different poultry sources. Singh (1997) reported that all of ground turkey meat samples of his study were contaminated with Aeromonas spp. where 56\% isolates were identified as A. hydrophila which is also nearly similar to present study. Higher and lower isolation rate of Aeromonas spp. from poultry sources compared to our findings have also been documented in previous study. Yucel and Citak (2003) detected motile aeromonads in $87 \%$ of poultry meat samples with predominance of Aeromonas hydrophila and Aeromonas sobria strains. Some other studies on chicken samples performed by Yucel and Erdem (2004), Sarımehmetoglu and Kuplulu (2001) and Hanninen (1993) had found a higher contamination levels of 86.95\%, 82.9\% and 93\% with Aeromonas spp. respectively compared to present findings. On the other hand lower recovery rate of Aeromonas hydrophila had also been reported by Nagar et al. (2011), Sharma et al. (2009) and Chang et al. (2008). Variations in the percentage of Aeromonas hydrophila may be due to the differences in the geographical distribution, origin of the samples, sampling period, methodology of analysis, number of samples for analysis and poor hygienic practices during handling and processing (Nagar et al., 2011; Sharma et al., 2009; Koca and Sarimehmetoglu, 2009).

Significant economic losses are being experienced in commercial poultry sector worldwide due to diseases caused by bacterial agents (Barnes et al., 2003). Many previous studies revealed that Aeromonas hydrophila to be found more frequently in meat and meat products (Dallal et al., 2012; Osman et al., 2012; Sharma and Kumar, 2011; Hanninen, 1993). It is probable that the A. hydrophila infection of chicken occurred horizontally via the oral route through drinking water from contaminated sources and unhygienic feeds containing contaminated fish meals or similar products (Dashe et al., 2013) as fish is considered to be the reservoir of $A$. hydrophila (Sharma et al., 2009). Whereas contamination of poultry meat with A. hydrophila is attributed to the washing of carcasses with contaminated water along with insufficent sanitary measures during their handling and processing (cutting and mincing) (Stratev and Odeyemi, 2016; Rajakumar et al., 2012; Stratev et al., 2012).

Table 2. Number (\%) of isolated Aeromonas hydrophila from different types of broiler samples collected from two different locations of Mymensingh Sadar.

\begin{tabular}{|c|c|c|c|c|c|c|}
\hline \multirow[b]{2}{*}{ Sample sources } & \multicolumn{3}{|c|}{ KR Market, Mymensingh Sadar } & \multicolumn{3}{|c|}{ Shesh mor, Mymensingh Sadar } \\
\hline & $\begin{array}{l}\text { No. of } \\
\text { sample } \\
\text { tested }\end{array}$ & $\begin{array}{l}\text { No. }(\%) \text { of } \\
\text { culture positive } \\
\text { isolates }\end{array}$ & $\begin{array}{l}\text { No. }(\%) \text { of } \\
\text { positive } A . \\
\text { hydrophila }\end{array}$ & $\begin{array}{l}\text { No. of } \\
\text { sample } \\
\text { tested }\end{array}$ & $\begin{array}{l}\text { No. }(\%) \text { of } \\
\text { culture positive } \\
\text { isolates }\end{array}$ & $\begin{array}{l}\text { No. }(\%) \text { of } \\
\text { positive } A \text {. } \\
\text { hydrophila }\end{array}$ \\
\hline Skin & 10 & $9(90)$ & $7(70)$ & 10 & $9(90)$ & $9(90)$ \\
\hline Leg & 10 & $6(60)$ & $3(30)$ & 10 & $6(60)$ & $3(30)$ \\
\hline Breast & 10 & $3(30)$ & $2(20)$ & 10 & $4(40)$ & $3(30)$ \\
\hline Total & 30 & $18(60)$ & $12(40)$ & 30 & $19(63.33)$ & $15(50)$ \\
\hline
\end{tabular}

In this present study, out of 27 positive isolates of Aeromonas hydrophila, 55.56\% isolates were recovered from shesh mor market (Figure 1). The reasons behind higher recovery of A. hydrophila from shesh mor market may be due to the use of a funnel like device for the bleeding of each birds after slaughtering that may act as a vehicle for transmission of pathogens. However, this device was not observed in KR market. Among three different samples of a bird, skin was found most contaminated part followed by leg and breast (Figure 2). This was happened because skin is the most outer part of a bird and always gets exposed to the faecal contamination. Aeromonas spp. are very sensitive to $\mathrm{pH}$ below 5.5 and 7.2 is considered as the optimum $\mathrm{pH}$ for growth (Kirov, 
1993). Koca and Sarimehmetoglu (2009) investigated and documented that average pH value of turkey leg samples was 6.0, on the other hand, 5.7 for breast samples. This finding also supports our present study and clarifies the higher susceptibility of leg samples to A. hydrophila over the breast samples.

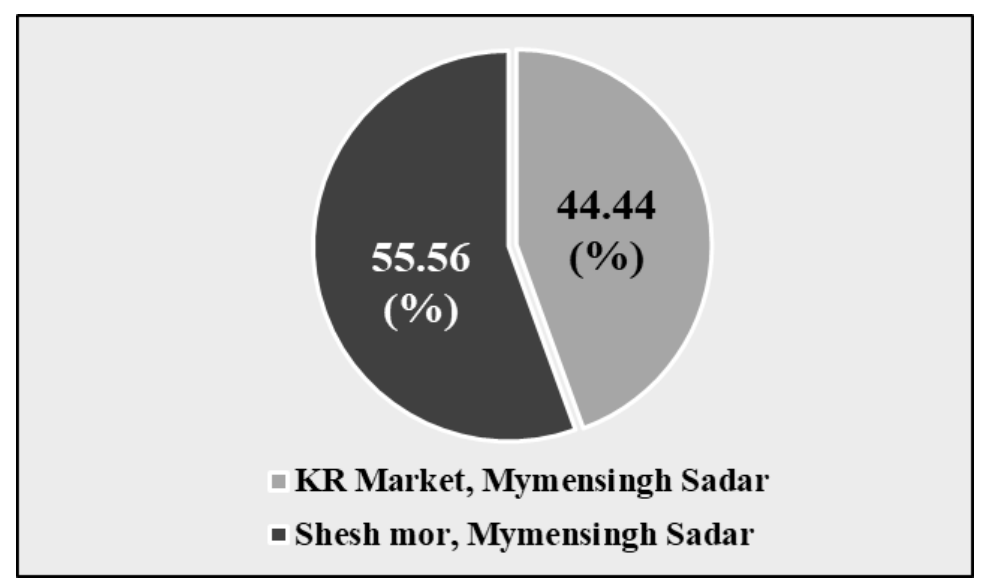

Figure 1. Location-wise percentage of $A$. hydrophila from 27 positive isolates.

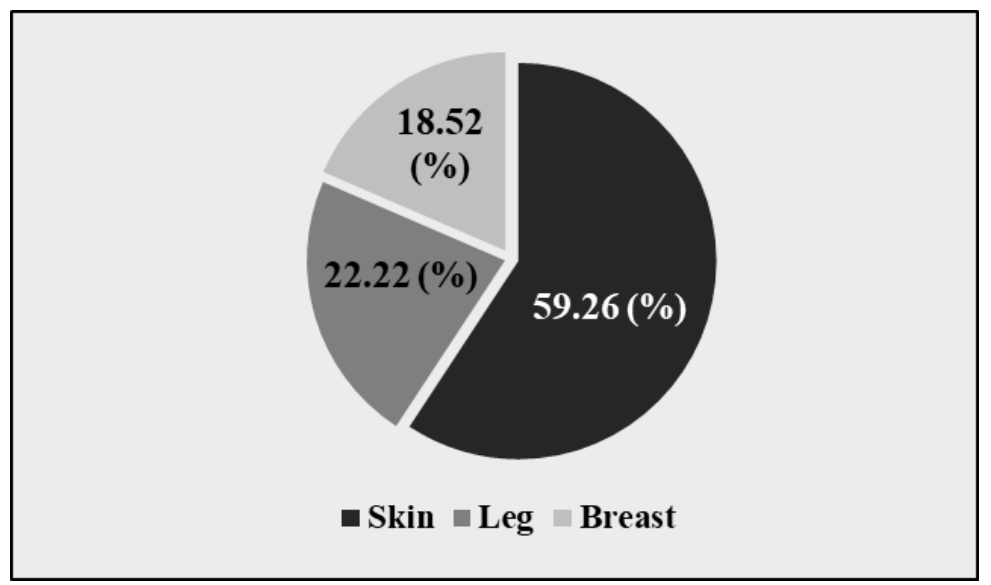

Figure 2. Sample-wise percentage of $A$. hydrophila from 27 positive isolates.

\subsection{Morphological and biochemical characterization}

The isolated A. hydrophila from were further identified based on the morphological, physiological, conventional, and biochemical characteristics. Morphologically the isolated colonies showed greenish with dark green centre, round, small to medium, convex and translucent colonies on Aeromonas Selective Agar plates (HiMedia, India). Microscopically A. hydrophila was a Gram negative short plump rod, motile by polar flagella with swarming movement, positive for oxidase and catalase test similar to the characteristics reported by Monir et al. (2017), Samal et al. (2014) and Noga (2000). The isolates were found to produce acid and gas from different sugar media such as glucose, lactose, sucrose, dextrose, maltose, mannitol, whereas did not ferment inositol, sorbitol, rhamnose etc. Moreover, they utilized citrate for growth and produced acetoin, produced indole, reduced nitrate, showed positive reaction towards Voges proskauer (VP) test, gelatinase test, arginine decarboxylase test; esculin hydrolysis test, alkyl sulfatase test, acetate utilization test; showed negative reaction towards methyl red (MR) test, lysine decarboxylase test, urease test (Monir et al., 2017; Ahammed et al., 2016; Samal et al., 2014; Jayavignesh et al., 2011; Mostafa and Ahamed, 2008). Consequently, the isolates showed positive growth at $37^{\circ} \mathrm{C}$ with the optimum at $24^{\circ} \mathrm{C}$ but no growth was found at $4{ }^{\circ} \mathrm{C}$ and $40^{\circ} \mathrm{C}$. Furthermore, $A$. hydrophila strains grow in nutrient broth with $0-2 \% \mathrm{NaCl}$, however, no growth was noted in $2-4 \% \mathrm{NaCl}$ media (Table 3). 
Table 3. Results of biochemical characteristics of the isolated bacteria.

\begin{tabular}{|c|c|c|c|}
\hline Characters & $\begin{array}{l}\text { Characterization by Ahammed } \\
\text { et al. (2016) }\end{array}$ & $\begin{array}{l}\text { Characterization by Mostafa } \\
\text { and Ahamed (2008) }\end{array}$ & Present result \\
\hline Gram stain & - & & - \\
\hline Shape & Rod & Rod & Rod \\
\hline Motility & + & + & + \\
\hline Oxidase & + & + & + \\
\hline Catalase & + & + & \\
\hline Glucose & + & + & + \\
\hline Lactose & + & + & + \\
\hline Sucrose & + & + & + \\
\hline Maltose & + & + & + \\
\hline Mannitol & + & + & - \\
\hline Inositol & - & - & - \\
\hline Sorbitol & - & - & - \\
\hline Rhamnose & - & - & - \\
\hline Esculin hydrolysis & + & + & + \\
\hline Methyl-red test & - & - & - \\
\hline Voges-Proskaur & + & + & + \\
\hline Indole & + & + & + \\
\hline $\mathrm{H}_{2} \mathrm{~S}$ production & + & + & - \\
\hline $\begin{array}{l}\text { Arginine } \\
\text { decarboxylation }\end{array}$ & + & + & + \\
\hline Lysine decarboxylation & - & - & - \\
\hline Citrate utilization & + & + & + \\
\hline Growth at: $4^{\circ} \mathrm{C}$ & - & - & - \\
\hline $5^{\circ} \mathrm{C}$ & + & + & + \\
\hline $37^{\circ} \mathrm{C}$ & + & + & + \\
\hline $40^{\circ} \mathrm{C}$ & - & - & - \\
\hline
\end{tabular}

\subsection{Molecular identificaction of Aeromonas hydrophila by PCR}

DNA extracted from all culture positive samples were used in the PCR assay for specific identification of Aeromonas hydrophila. PCR primers targeting lip gene in the isolated genomic DNA of Aeromonas hydrophila amplified 760 bp that confirmed the identity of Aeromonas hydrophila (Figure 3). PCR product of 760 bp was obtained in 27 isolates of $A$. hydrophila out of 37 culture positive samples (Table 2).

lip gene codes for a thermostable extra cellular lipase of $A$. hydrophila and the PCR primers containing lip gene are designed for the specific detection of A. hydrophila (Swaminathan et al., 2004). Cascon et al. (1996) screened 50 strains of bacteria including Aeromonas spp., through amplification of lip gene. A DNA fragment of approximately $760 \mathrm{bp}$ was amplified only in the strains of A. hydrophila. Swaminathan et al. (2004) identified nine isolates of $A$. hydrophila from fish and water samples by amplification of the lip gene through known primer sequences at a modified annealing temperature.

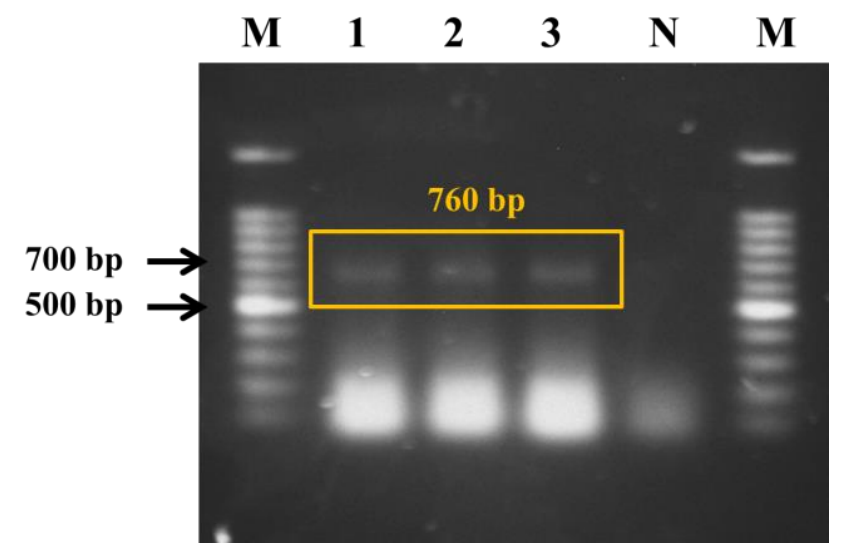

Figure 3. lip gene-based PCR of Aeromonas hydrophila showing positive band at 760 bp. Lane M: 100 bp DNA ladder; lane N: negative control; lanes 1-3: positive samples of Aeromonas hydrophila. 


\subsection{Antimicrobial susceptibility testing}

Out of 27 isolated Aeromonas hydrophila, randomly 12 isolates (6 from each location) were tested against eight commercially available and widely used antibiotics in poultry industry of Bangladesh namely ampicillin, ciprofloxacin, gentamicin, chloramphenicol, erythromycin, co-trimoxazole, imipenem and tetracycline. The isolates of Aeromonas hydrophila showed varying levels of susceptibility/resistance to the different antimicrobial agents (Table 4).

All Aeromonas hydrophila strains were found resistant to ampicillin and few isolates showed higher resistance to co-trimoxazole (84\%), tetracycline (34\%) and erythromycin (34\%). Higher resistance to $\beta$-lactamases like ampicillin had also been reported by some other researchers (Samal et al., 2014; Nagar et al., 2011; Vaseeharan et al., 2005; Radu et al., 2003). The high resistance is due to the production of inducible chromosomal $\beta$ lactamases (Janda and Abbott, 2010). In this present study, most of the isolates were found sensitive to ciprofloxacin (92\%), gentamycin (66\%), chloramphenicol (50\%) and Imipenem (34\%) as reported by Monir et al. (2017), Nagar et al. (2011), Ashiru et al. (2011), Akinbowale et al. (2007), Palu et al. (2006) and Ottaviani et al. (2006). The sensitivity and resistance pattern of Aeromonas may vary due to different isolation sources, environmental conditions, and variable use of drug from place to place (Nagar et al., 2011).

Table 4. Antibiogram profile of the isolated Aeromonas hydrophilla $(\mathrm{n}=12)$.

\begin{tabular}{llll}
\hline Antibiotics & \multicolumn{1}{c}{$\begin{array}{c}\text { No. (\%) } \\
\text { Sensitive }\end{array}$} & $1(8)$ & $0(0)$ \\
\hline Ciprofloxacin $(5 \mu \mathrm{g})$ & $11(92)$ & $4(34)$ & $0(0)$ \\
Gentamicin $(10 \mu \mathrm{g})$ & $8(66)$ & $6(50)$ & $4(34)$ \\
Tetracycline $(30 \mu \mathrm{g})$ & $2(16)$ & $4(34)$ & $2(16)$ \\
Chloramphenicol $(30 \mu \mathrm{g})$ & $6(50)$ & $6(50)$ & $4(34)$ \\
Erythromycin $(15 \mu \mathrm{g})$ & $2(16)$ & $2(16)$ & $10(84)$ \\
Co-trimoxazole $(25 \mu \mathrm{g})$ & $0(0)$ & $0(0)$ & $12(100)$ \\
Ampicillin $(10 \mu \mathrm{g})$ & $0(0)$ & $6(50)$ & $2(16)$ \\
Imipenem $(10 \mu \mathrm{g})$ & $4(34)$ & & \\
\hline
\end{tabular}

\section{Conclusions}

In conclusion, the findings of the present study indicate the involvement of A. hydrophila in apparently healthy broiler chickens. In addition, Aeromonas hydrophila isolates were found resistance to a variety of commercially available antibiotics due to indiscriminate and irrational use in poultry sector. Hence, intensive and continuous monitoring of potentially pathogenic Aeromonas spp. along with their antibiogram profile from the poultry value chain in Bangladesh are highly recommended to assess the human health risk.

\section{Acknowledgements}

The authors would like to thank all the staffs of the Department of Microbiology and Hygiene, Bangladesh Agricultural University, Mymensingh-2202, Bangladesh for providing continuous support and sincere cooperation.

\section{Conflict of interest}

None to declare.

\section{References}

Ahammed T, SC Borty, MS Monir, N Begum, MA Islam and SML Kabir, 2016. Isolation, identification and molecular detection of Aeromonas hydrophila from diseased stinging catfish Shing (Heteropneustes fossilis). Asian Australas. J. Biosci. Biotechnol., 1: 125-133.

Akinbowale OL, H Peng, P Grant and MD Barton, 2007. Antibiotic and heavy metal resistance in motile aeromonads and pseudomonads from rainbow trout (Oncorhynchus mykiss) farms in Australia. Int. J. Antimicrob. Agents, 30: 177-182.

Akond MA, S Alam, SM Hassan and M Shirin, 2009. Antibiotic resistance of Escherichia coli isolated from poultry and poultry environment of Bangladesh. Internet Journal of Food Safety, 11: 19-23.

Albert MJ, M Ansaruzzaman, KA Talukder, AK Chopra, I Kuhn, M Rahman, AS Faruque, MS Islam, RB Sack and R Mollby, 2000. Prevalence of enterotoxin genes in Aeromonas spp. isolated from children with diarrhea, healthy controls, and the environment. J. Clin. Microbiol., 38: 3785-3790. 
Ashiru AW, PO Uaboi-Egbeni, JE Oguntowo and CN Idika, 2011. Isolation and antibiotic profile of Aeromonas species from tilapia fish (Tilapia nilotica) and catfish (Clarias betrachus). Pak. J. Nutr., 10: 982-986.

Bagde NI and PM Tumane, 2011. Studies on microbial flora of fruit juices and cold drinks. Asiat. J. Biotechnol. Resour., 2: 454-460.

Bailey JS and DE Cosby, 2003. Detection of Salmonella from chicken rinses and chicken hot dogs with the automated BAX PCR system. J. Food Prot., 66: 2138-2140.

Barnes HJ, JP Vaillancourt and WB Gross, 2003. Collibacillosis In: Diseases of poultry, 11th Ed. YM Saif, ed. Iowa State Press, Iowa City, IA., pp. 631-656.

Bauer AW, WMM Kirby, JC Sherris and M Turck, 1996. Antibiotic susceptibility testing by a standardized single disk method. Am. J. Clin. Pathol., 45: 493-496.

Cascon A, J Anguita, C Hernanz, M Sánchez, M Fernandez and G Naharro, 1996. Identification of Aeromonas hydrophila hybridization group 1 by PCR assays. Appl. Environ. Microbiol., 62: 1167-1170.

Chang YC, JY Wang, A Selvam, SC Kao, SS Yang and DY Shih, 2008. Multiplex PCR detection of enterotoxin genes in Aeromonas spp. from suspect food samples in northern Taiwan. J. Food Prot., 71: 2094-2099.

Dallal MS, MS Yazdi and S Avadisians, 2012. Study of prevalence and antibiotic resistance in Aeromonas species isolated from minced meat and chicken samples in Iran. Afr. J. Microbiol. Res., 6: 460-464.

Dashe YG, MA Raji, PA Abdu and BS Oladele, 2013. Aeromonas hydrophila infections in chickens affected by fowl cholera in Jos Metropolis, Nigeria. International Journal of Microbiology and Immunology Research, 1: 32-36.

Fricker CR and S Tompsett, 1989. Aeromonas spp. in foods: a significant cause of food poisoning. Int. J. Food Microbiol., 9: 17-23.

Garibay RI, MG Aguilera-Arreola, AN Ocania, SG Cerezo, MS Mendoza, JM Lopez, CE Campos, A Cravioto and G Castro-Escarpulli, 2006. Serogroups, K1 antigen, and antimicrobial resistance patterns of Aeromonas spp. strains isolated from different sources in Mexico. Mem. Inst. Oswaldo Cruz, 101: 157-161.

Ghenghesh KS, SF Ahmed, RA El-Khalek, A Al-Gendy and J Klena, 2008. Aeromonas-associated infections in developing countries. J. Infect. Dev. Countr., 2: 81-98.

Gowda TK, VR Reddy, B Devleesschauwer, NN Zade, SP Chaudhari, WA Khan, SV Shinde and AR Patil, 2015. Isolation and seroprevalence of Aeromonas spp. among common food animals slaughtered in Nagpur, Central India. Foodborne Pathog. Dis., 12: 626-630.

Hanninen ML, 1993. Occurrence of Aeromonas spp. in samples of ground meat and chicken. Int. J. Food Microbiol., 18: 339-342.

Iyayi EA, 2008. Prospects and challenges of unconventional poultry feedstuffs. Nigerian Poultry Science Journal, 5: 186-194.

Janda JM and SL Abbott, 2010. The genus Aeromonas: taxonomy, pathogenicity, and infection. Clin. Microbiol. Rev., 23: 35-73.

Jayavignesh V, KS Kannan and AD Bhat, 2011. Biochemical characterization and cytotoxicity of the Aeromonas hydrophila isolated from Catfish. Arch. Appl. Sci. Res., 3: 85-93.

Khajanchi BK, AA Fadl, MA Borchardt, RL Berg, AJ Horneman, ME Stemper, SW Joseph, NP Moyer, J Sha and AK Chopra, 2010. Distribution of virulence factors and molecular fingerprinting of Aeromonas species isolates from water and clinical samples: suggestive evidence of water-to-human transmission. Appl. Environ. Microb., 76: 2313-2325.

Kirov SM, 1993. The public health significance of Aeromonas spp. in foods. Int. J. Food Microbiol., 20: 179198.

Koca C and B Sarimehmetoglu, 2009. Isolation and identification of motile Aeromonas spp. in turkey meat. Ankara Üniv. Vet. Fak. Derg., 56: 95-98.

Monir MS, N Bagum, SM Kabir, SC Borty and MA Ud-Doulah, 2017. Isolation, molecular identification and characterization of Aeromonas hydrophila from infected air-breathing catfish Magur (Clarias batrachus) cultured in Mymensingh, Bangladesh. Asian Australas. J. Food Saf. Secur., 1: 17-24.

Mostafa M and F Ahamed, 2008. Pethogenesis of Aeromonas hydrophila on Heteropneustes fossilis. Bangladesh J. of Fis., 8: 38-41.

Nagar V, R Shashidhar and JR Bandekar, 2011. Prevalence, characterization, and antimicrobial resistance of Aeromonas strains from various retail food products in Mumbai, India. J. Food Sci., 76: M486-M492.

Noga EJ, 2000. Skin ulcers in fish: Pfiesteria and other etiologies. Toxicol. Pathol., 28: 807-823.

Osman K, M Aly, A Kheader and K Mabrok, 2012. Molecular detection of the Aeromonas virulence aerolysin gene in retail meats from different animal sources in Egypt. World J. Microb. Biot., 28: 1863-1870. 
Ottaviani D, S Santarelli, S Bacchiocchi, L Masini, C Ghittino and I Bacchiocchi, 2006. Occurrence and characterization of Aeromonas spp. in mussels from the Adriatic Sea. Food Microbiol., 23: 418-422.

Palu AP, LM Gomes, MA Miguel, IT Balassiano, ML Queiroz, AC Freitas-Almeida and SS de Oliveira, 2006. Antimicrobial resistance in food and clinical Aeromonas isolates. Food Microbiol., 23: 504-509.

Praveen PK, C Debnath, AK Pramanik, S Shekhar and N Dalai. Incidence and biochemical characterization of Aeromonas species isolated from retail fish and chicken in North Kolkata region. Journal of Cell and Tissue Research, 14: 4609.

Praveen, P.K., Debnath, C., Pramanik, A.K., Shekhar, S. and Dalai, N. (2014). Incidence and biochemical characterization of Aeromonas species isolated from retail fish and chicken in North Kolkata region. Journal of Cell and Tissue Research, 14: 4609.

Radu S, N Ahmad, FH Ling and A Reezal, 2003. Prevalence and resistance to antibiotics for Aeromonas species from retail fish in Malaysia. Int. J. Food Microbiol., 81: 261-266.

Rajakumar S, PM Ayyasamy, K Shanthi, YC Song and P Lakshmanaperumalsamy, 2012. Incidence, Survival and Antibiotic Resistance of Aeromonas hydrophila Isolated From Lamb and Chicken Meat Retail Outlets. Journal of Current Perspectives in Applied Microbiology, 2278: 1250.

Samal SK, BK Das and BB Pal, 2014. Isolation, biochemical characterization, antibiotic susceptibility study of Aeromonas hydrophila isolated from freshwater fish. Int. J. Curr. Microbiol. Appl. Sci., 3: 259-267.

Sarimehmetoglu B and O Kuplulu, 2001. Isolation and identification of motile Aeromonas species from chicken. Deut. Tierarztl. Woch., 108: 465.

Sharma I and A Kumar, 2011. Occurrence of enterotoxigenic Aeromonas species in foods of animal origin in North East India. Eur. Rev. Med. Pharmacol. Sci., 15: 883-887.

Sharma I, A Kumar and AK Pramanik, 2009. Isolation and identification of mesophillic Aeromonas bacteria from meat and fish foods of North East India. J. Pure Appl. Microbiol., 3: 517-526.

Singh U, 1997. Isolation and identification of Aeromonas spp. from ground meats in Eastern Canada. J. Food Prot, 60: 125-130.

Soultos N, P Koidis and RH Madden, 2003. Presence of Listeria and Salmonella spp. in retail chicken in Northern Ireland. Lett. Appl. Microbiol., 37: 421-423.

Stelma GN, 1988. Virulence factors assocaited with pathogenicity of Aeromonas isolates. J. Food Saf., 9: 1-4.

Stratev D and OA Odeyemi, 2016. Antimicrobial resistance of Aeromonas hydrophila isolated from different food sources: A mini-review. J. Infect. Public. Heal., 9: 535-544.

Stratev D, I Vashin and V Rusev, 2012. Prevalence and survival of Aeromonas spp. in foods-a review. Rev. Med. Vet., 163: 486-494.

Swaminathan TR, G Rathore, R Abidi and D Kapoor, 2004. Detection of Aeromonas hydrophila by polymerase chain reaction. Indian J. Fish., 51: 251-254.

Ternstrom A and G Molin, 1987. Incidence of potential pathogens on raw pork, beef and chicken in Sweden, with special reference to Erysipelothrix rhusiopathiae. J. Food Prot., 50: 141-146.

Vaseeharan B, P Ramasamy, T Murugan and JC Chen, 2005. In vitro susceptibility of antibiotics against Vibrio spp. and Aeromonas spp. isolated from Penaeus monodon hatcheries and ponds. Int. J. Antimicrob. Agents, 26: $285-291$.

Wei LS, MT Mustakim, IN Azlina, AK Zulhisyam, MN An'amt, W Wee and NM Huang, 2015. Antibiotic and heavy metal resistance of Aeromonas spp. isolated from diseased red hybrid tilapia (Oreochromis sp.). Annu. Res. Rev. Biol., 26: 264-269.

Wei LS, MT Mustakim, IN Azlina, AK Zulhisyam, MN An'amt, W Wee and NM Huang, 2015. Antibiotic and heavy metal resistance of Aeromonas spp. isolated from diseased red hybrid tilapia (Oreochromis sp.). Annu. Res. Rev. Biol., 26: 264-269.

Windhorst HW, 2006. Changes in poultry production and trade worldwide. World Poultry Sci. J., 62: 585-602.

Yucel N and B Erdem, 2004. The isolation and identification of motile Aeromonas spp. from meats in Ankara, Turkey. Indian Vet. J., 81: 967-970.

Yucel N and S Citak, 2003. The occurrence, hemolytic activity and antibiotic susceptibility of motile Aeromonas spp. isolated from meat and milk samples in Turkey. J. Food Saf., 23: 189-200.

Yucel N and S Erdogan, 2010. Virulence properties and characterization of aeromonads isolated from foods of animal origin and environmental sources. J. Food Prot., 73: 855-860. 